In cooperation with the Indiana Department of Environmental Management and the Indiana Department of Natural Resources Division of Water

\title{
Digital Data Set of 14-Digit Hydrologic Units in Indiana
}

\begin{abstract}
A hydrologic unit is an area of land that can contribute surface-water runoff to a designated outlet point. As part of an initiative to create a nationally uniform hydrologic-unit data base, the U.S. Geological Survey and the Natural Resources Conservation Service, in cooperation with the Indiana Department of Environmental Management and the Indiana Department of Natural Resources Division of Water, created a geographic information system digital data set of 14-digit hydrologic units in Indiana. The digital data set consists of arcs and polygons defining 14-digit hydrologic units in Indiana.
\end{abstract}

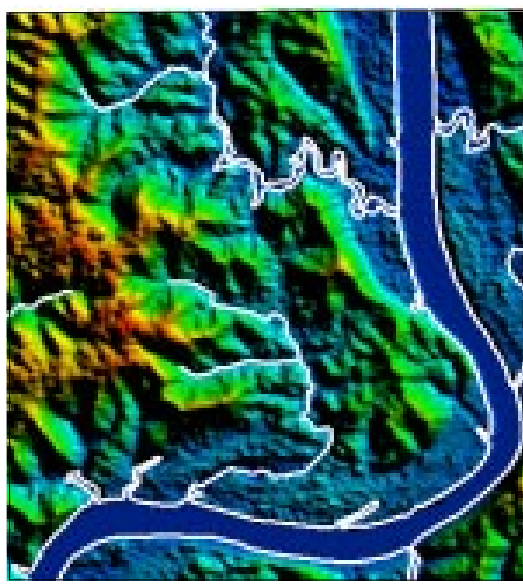

Three-dimensional view of land surface

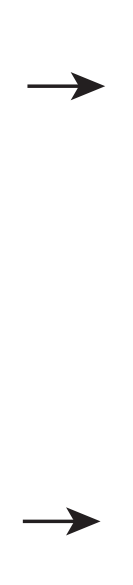

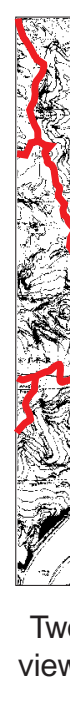
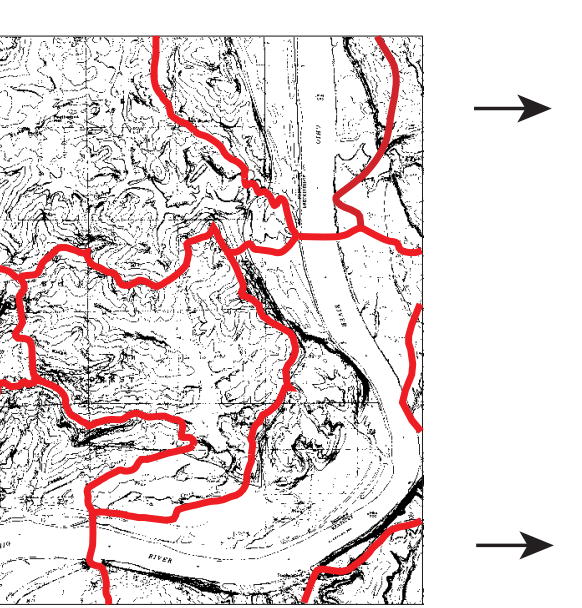

wo-dimensional topographic map with drainage-basin boundaries in red

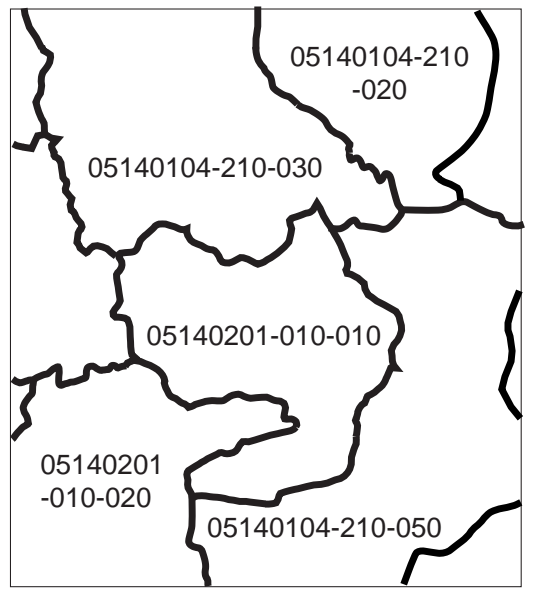

Digital data set of 14-digit basin boundaries with hydrologic-unit codes

Diagram illustrating development of hydrologic units, progressing from a three-dimensional land surface to a two-dimensional topographic map to a digital data set.

\section{Introduction}

A hydrologic unit (HU) is an area of land upstream from a specific point on a stream that is defined by a hydrologic boundary. The boundary includes all of the source area that could contribute surface-water runoff directly or indirectly to the designated outlet point. HU's are used by local, State, and Federal agencies and by private and academic interests for natural-resource, water-quality, and flood-damage activities; water-data management; and geographic information systemsbased (GIS-based) spatial analyses (U.S. Department of Agriculture, 1992).

Before 1999, the most-detailed statewide hydrologic-unit data for Indiana were published on a 1:500,000scale map of 8-digit hydrologic-unit boundaries (U.S. Geological Survey, 1974). That map was part of a series developed by the U.S. Geological Survey (USGS) to provide uniform hydrologic-unit boundaries and to present them on nationally consistent base maps.
The 8-digit HU's in Indiana are identified by a unique 8-digit hydrologic-unit code (HUC) based on four levels of classification (fig. 1, page 3): regions, subregions, accounting units, and cataloging units (Seaber and others, 1987). During the mid- to late-1970's, the U.S. Department of Agriculture Natural Resources Conservation Service (NRCS) subdivided 8-digit HU's by adding three digits to identify a fifth level of classification, 11-digit HU's-watersheds. 
Since that time, water-resources professionals have recognized a need for further delineation and subdivision of HU's in Indiana for research, planning, and regulatory activities. In 1992, the NRCS developed guidelines for mapping and digitizing a sixth level of classification, 14-digit HU'ssubwatersheds (U.S. Department of Agriculture, 1992). In 1996, the USGS, the NRCS, the Indiana Department of Environmental Management, and the Indiana Department of Natural Resources Division of Water agreed to create a digital data set of 14-digit HU's in Indiana.

\section{Creation of Digital Data Set of 14-Digit Hydrologic Units}

The USGS office in Indianapolis maintains a file of 1:24,000-scale topographic maps with hand-drawn drainage-basin boundaries for all waterways in Indiana with drainage areas greater than 5 square miles. Many basins have been subdivided into drainage areas smaller than 5 square miles. These topographic maps have been used to calculate drainage areas-an important parameter in many hydrologic analyses (Hoggatt, 1975).

A GIS base-map coverage containing coordinate points at every 7.5 minutes of latitude and longitude was generated. The coordinate points correspond to the corner vertices of 1:24,000-scale topographic maps for Indiana and the immediate vicinity. For each topographic map, a root mean square error (RMSE) was calculated on the distances between the four corner vertices and the corresponding coordinate points in the base-map coverage. RMSE values were 0.010 or less for 95 percent of the maps, indicating potential distortions of 20 feet or less. The remaining 5 percent of the maps had RMSE values between 0.011 and 0.016 , indicating potential distortions of up to 32 feet.

The hand-drawn drainage-basin boundaries were digitized into the base-map coverage, using $\mathrm{ARC} / \mathrm{INFO}^{1}$ software

\footnotetext{
${ }^{1}$ The use of trade, product, or firm names is for descriptive purposes only and does not imply endorsement by the U.S. Government.
}

Table 1. User-defined polygon attributes

\begin{tabular}{lll}
\hline \multicolumn{1}{c}{ Attribute name } & \multicolumn{1}{c}{ Description } & \multicolumn{1}{c}{ Example } \\
\hline HUC_8 & 8-digit hydrologic-unit code & 04040001 \\
HUC_11 & 11-digit hydrologic-unit code & 04040001070 \\
HUC_14 & 14-digit hydrologic-unit code & 04040001070020 \\
HU_NAME & Name of 14-digit hydrologic unit & West Branch Trail Creek \\
HU_ACRES & $\begin{array}{c}\text { Area of 14-digit hydrologic unit, } \\
\text { in acres }\end{array}$ & 15349.2 \\
NONCONTRIB_ACRES & $\begin{array}{c}\text { Area of noncontributing part of } \\
\text { 14-digit hydrologic unit, in } \\
\text { acres }\end{array}$ & 907.4 \\
& & \\
\hline
\end{tabular}

and adhering to the digitizing accuracy standard of \pm 50 feet (U.S. Department of Agriculture, 1992). All drainagebasin boundaries were plotted on paper and overlain on the original maps to determine the accuracy of the digitized lines. Lines that did not meet the digitizing accuracy standard were redigitized and replotted. This procedure was repeated until all lines met the standard. A second person not involved with the original digitizing followed the same line-verification procedures for 36 percent of the original topographic maps. Less than 3 percent of these maps had errors, and those errors were corrected.

Each delineated basin was attributed with a 14-digit HUC assigned by NRCS personnel. Drainage basins with the same 14-digit HUC were merged to form the final digital data set of 14-digit HU's. For each topographic map, the HU boundaries and respective HUC's were plotted on paper and reviewed by NRCS personnel. Errors were noted and corrected, and new plots were produced and reviewed until no errors were identified.

NRCS personnel assigned each 14-digit $\mathrm{HU}$ a unique name based on the main waterway within that HU. Names were checked for accuracy by NRCS and USGS personnel.

\section{Digital Data Set of 14-Digit Hydrologic Units}

The digital data set consists of polygons (areas) and arcs (lines) representing 14-digit HU's in Indiana. Each polygon has an associated record in a polygon-attribute table (table 1) listing its 8-, 11-, and 14-digit HUC; the name of the 14-digit HU; the HU area in acres; and the noncontributing part of the HU area in acres.

Each arc has an associated record in an arc-attribute table (table 2, page 4) that identifies the arc as a 2-, 4-, 6-, 8-, 11-, or 14-digit HU boundary or the Indiana State line. Quality-assurance data regarding the digitization of each arc also are included in the arc-attribute table. The data set is documented and meets the Federal Geographic Data Committee standards for digital geospatial data sets (Federal Geographic Data Committee, 1998).

\section{Data Availability}

This fact sheet, the digital data set, and the data-set documentation ("metadata") are available at the USGS Indiana District homepage:

\section{http://in.water.usgs.gov}

under the heading, "Indiana District Publications Available on the Web."

The HU data set for the entire State of Indiana is available for downloading as a compressed ARC/INFO export file (approximately 46 megabytes) or a spatial data transfer standard (SDTS) file (approximately 23 megabytes). The data set for the State also is divided along accounting-unit boundaries to provide smaller files for downloading (compressed ARC/INFO files, approximately 0.2 to 18 megabytes, or SDTS files, approximately 0.1 to 9 megabytes). 


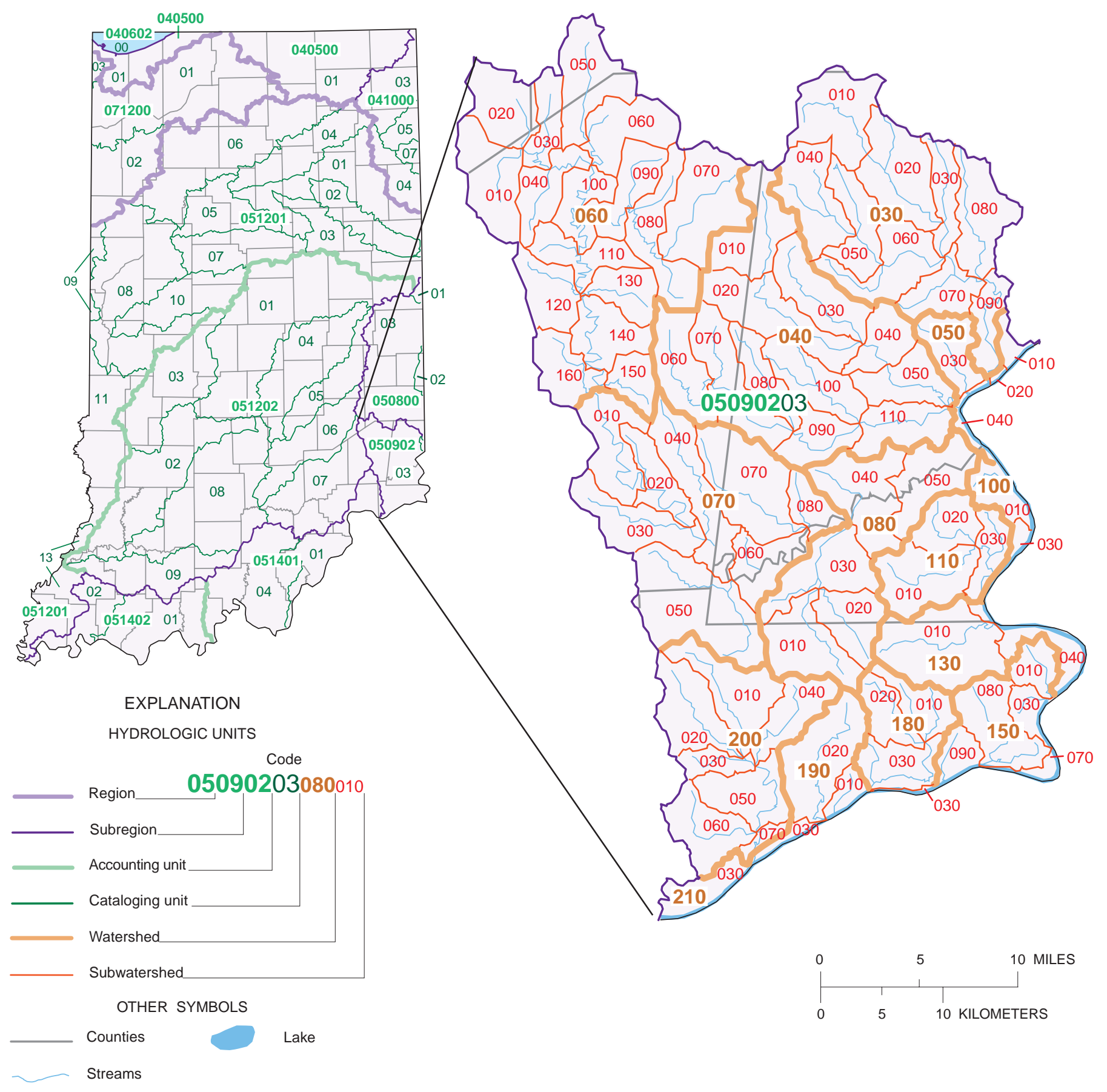

EXPLANATION

HYDROLOGIC-UNIT TERMS

Regions are the largest drainage basins and contain either the drainage area of a major river or the combined drainage areas of several rivers.

Subregions divide the regions and include the area drained by a river system.

Accounting units divide or may be equivalent to subregions.
Cataloging units divide accounting units and represent part or all of a surface-drainage basin, a combination of drainage basins, or a distinct hydrologic feature.

Watersheds divide cataloging units and generally range in size from 40,000 to 250,000 acres.

Subwatersheds divide or may be equivalent to watersheds and generally range in size from 10,000 to 40,000 acres.

Figure 1. Hydrologic units in Indiana 
Table 2. User-defined arc attributes

\begin{tabular}{|c|c|c|}
\hline Attribute name & Description & Example \\
\hline QUADNAME & $\begin{array}{l}\text { Name of the topographic map on which the drainage-basin } \\
\text { boundary was determined }\end{array}$ & CABORN \\
\hline QUAD_PUB_DATE & $\begin{array}{l}\text { Publication date of the topographic map on which the drainage-basin } \\
\text { boundary was determined }\end{array}$ & 1957 \\
\hline DIGITIZE_DATE & Date the drainage-basin boundary was digitized & 19970616 \\
\hline RMSE & $\begin{array}{l}\text { Root mean square error for the transformation from the topographic } \\
\text { map to the digital coverage }\end{array}$ & 0.009 \\
\hline ARC_QA_DATE & $\begin{array}{l}\text { Date the digitized drainage-basin boundary was checked by someone } \\
\text { other than the person who digitized the boundary }\end{array}$ & 19980201 \\
\hline ARC_REMARKS & $\begin{array}{l}\text { Relevant remarks regarding the digitized drainage-basin } \\
\text { boundary }\end{array}$ & $\begin{array}{l}\text { Divides near Ohio River, } \\
\text { modified per } 1978 \\
\text { edition of map }\end{array}$ \\
\hline HU_DIV & Identifies arc as a 2-, 4-, 6-, 8-, 11-, or 14-digit divide or the State line & 14 \\
\hline
\end{tabular}

\section{Potential Need for Updates}

Continuing natural processes and human activities often change drainage patterns and therefore alter hydrologic-unit boundaries. Such changes would necessitate periodic updates to maintain an accurate data set for hydrologic calculations. Revisions of this data set ideally would incorporate observations from and meet the needs of public, private, and government interests.

\section{References Cited}

Federal Geographic Data Committee, 1998, FGDC-STD-001-1998, Content standard for digital geospatial metadata: Washington, D.C., Federal Geographic Data Committee, accessed September 24, 1998, at URL http://www.fgdc.gov/ metadata/contstan.html

Hoggatt, R.E., 1975, Drainage areas of Indiana streams: U.S. Geological Survey, $231 \mathrm{p}$.

Seaber, P.R., Kapinos, F.P., and Knapp, G.L., 1987, Hydrologic unit maps:
U.S. Geological Survey WaterSupply Paper 2294, p. 1-13.

U.S. Department of Agriculture, Natural Resources Conservation Service, 1992, Mapping and digitizing watershed and subwatershed hydrologic unit boundaries: National Instruction no. 170-304, 26 p., accessed May 30, 1997, at URL http:// www.nhq.nrcs.usda.gov/hu/ ni170304.html

U.S. Geological Survey, 1974, Hydrologic unit map-1974, State of Indiana: U.S. Geological Survey, 1 sheet, scale 1:500,000.

\section{Prepared by}

Krysten M. DeBroka and David A. Cohen, U.S. Geological Survey

Robert E. Dunn and Bruce J. Nielsen, Natural Resources Conservation Service

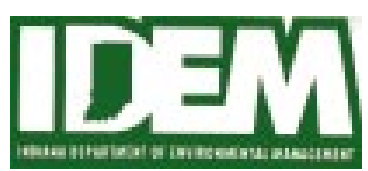

District Chief

U.S. Geological Survey

5957 Lakeside Boulevard

Indianapolis, IN 46278

317-290-3333

e-mail: dc_in@usgs.gov

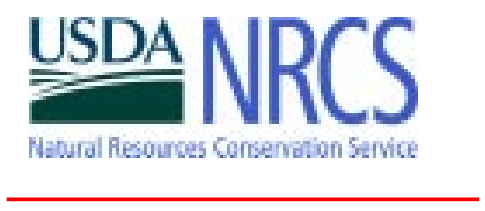

For More Information

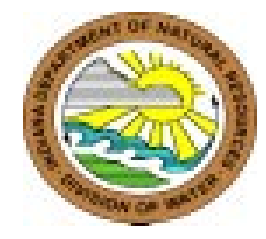

Indiana District Website http://in.water.usgs.gov

U.S. Geological Survey Website http://www.usgs.gov 